\title{
Litigating climate change through international law: Obligations strategy and rights strategy
}

\author{
Maiko Meguro ${ }^{1}$ \\ Amsterdam Centre for International Law, University of Amsterdam, Nieuwe Achtergracht 166, 1018WV Amsterdam, \\ the Netherlands \\ Email: M.Meguro@uva.nl
}

\begin{abstract}
Litigation has presented itself as a serious means to vindicate normative commitments about climate change by forcing governments to review their policy priorities. Today, the use of such litigation is not limited to the domestic arena. International law now provides the new principal avenue for such litigation. Two litigation strategies stand out: obligations strategy and rights strategy. Obligations strategy consists of bestowing an erga omnes character to existing obligations regarding the protection of the global environment, thereby providing standing for a non-injured party before international courts. Rights strategy, on the other hand, significantly increases in practice. It consists in the invocation, before national and international courts, of remedies for environmental damages through the legal categories of human rights law.

This article sheds light on the potential and limits of these litigation strategies in international law. The argument builds on the specific evolution in the legal architecture of international obligations under the United Nations Framework Convention on Climate Change (UNFCCC). The current structure of the UNFCCC now makes it substantially impossible to bring a claim against individual states regarding their specific measures against climate change. The article, by referring to the history of drafting which produced the specific structure, questions the ability of these litigation strategies to remedy the lack of international consensus and to accommodate the technical intricacy of how to turn normative commitments into actual action for climate change.
\end{abstract}

Keywords: climate change; erga omnes; human rights; international dispute settlement; state responsibility

\section{Introduction: Vindicating normative commitments on environmental protection}

Among all global environmental problems, climate change poses unprecedented challenges to existing legal orders for its poly-centric, socio-economically, and socio-politically complex nature. It is challenging, not only because of scientific uncertainty or the difficulty of identifying legally responsible parties, ${ }^{2}$ but also because of the difficulty in turning normative commitments into actual collective actions. The difficulty is due, among other things, to a lack of consensus on the content, scale and timing of such actions for each state, ${ }^{3}$ which has, in turn, led to political

\footnotetext{
${ }^{1}$ I am very grateful for comments by Takahiro Ueno, Iș1 Aral, Letizia Lo Giacco, and the negotiators of the UNFCCC who asked their names not to be disclosed. I also thank the anonymous reviewers. The views expressed in this article are the author's own and do not reflect any organizations' positions.

${ }^{2}$ E. Fisher, 'Environmental Law as "Hot” Law', (2013) 25 Journal of Environmental Law 347, at 350.

${ }^{3}$ As to this multi-layered stricture of governance on climate change, see R. Keohane and D. G. Victor, 'The Regime Complex for Climate Change', Harvard Project on Climate Agreements, January 2010, available at www.belfercenter.org/sites/default/ files/legacy/files/Keohane_Victor_Final_2.pdf; T. Etty et al., 'Transnational Climate Law', (2018) 7 Transnational Environmental Law 191; R. Agarwala, 'Towards a Global Compact for Managing Climate Change', Harvard Project on 
paralysis in taking action at all levels of governance. ${ }^{4}$ In this context, it is no surprise that litigation ${ }^{5}$ has presented itself as a serious alternative to vindicate normative commitments about climate change by forcing governments to review their policy priorities. ${ }^{6}$

The resort to litigation to vindicate normative commitments, especially in relation to the protection of the environment, is not entirely new. ${ }^{7}$ At the domestic level, there was some earlier successful litigation based on environmental administrative law, such as Massachusetts v. Environmental Protection Agency in the United States, ${ }^{8}$ Gray v. the Minister for Planning in Australia, ${ }^{9}$ or on constitutional rights such as Ashgar Leghari v. Federation of Pakistan. ${ }^{10}$ As a result of those judgments, governments have been required to substantially review their environmental policies. Today, the use of litigation to vindicate normative commitments is not limited to claims based on domestic law. International law now provides the new principal avenue for such litigation.

Litigation of global environmental issues was once considered, if not impossible, very difficult. Yet, nowadays, international lawyers have devised varied strategies to ease access to the domestic and international judiciary on the basis of international law, with a view to vindicating normative commitments about protection of the environment. Among them, two litigation strategies stand out at this time. One is what is designated here as the obligations strategy. This strategy consists of bestowing an erga omnes character to existing obligations related to the protection of the global environment, thereby providing for standing for a non-injured party before international courts. ${ }^{11}$

International Climate Agreements, December 2008, available at www.belfercenter.org/sites/default/files/files/publication/ AgarwalaWeb.pdf; D. Bodansky and E. Diringer, 'The Evolution of Multilateral Regimes: Implications for Climate Change', Pew Center on Global Climate Change, December 2010, available at www.c2es.org/site/assets/uploads/2010/12/evolutionmultilateral-regimes-implications-climate-change.pdf; E. Ostrom, Governing the Commons: The Evolution of Institutions for Collective Actions (1990).

${ }^{4}$ For the illustration of political paralysis see K. Levin et al., 'Overcoming the tragedy of super wicked problems: constraining our future selves to ameliorate global climate change', (2012) 45 Political Science 123, at 127-9. In the same vein, Al Gore called climate change 'issues of hell'. See A. Gore, The Future: Six Drivers of Global Change (2013), at 314.

${ }^{5}$ CClimate change litigation' can be defined in different ways. See, e.g., Part II of J. Peel and J. Lin, 'Transitional Climate Litigation: the Contribution of the Global South', (2019) 113 AJIL 679.

${ }^{6}$ For the latest statistics, climate change litigations are identified in at least 28 countries with more than 1,320 cases. See J. Setzer and R. Byrnes, 'Global trends in climate change litigation: 2019 snapshot', LSE, July 2019, available at www.lse.ac.uk/ GranthamInstitute/wp-content/uploads/2019/07/GRI_Global-trends-in-climate-change-litigation-2019-snapshot-2.pdf. See also J. Setzer and L. C. Vanhala, 'Climate change litigation: A review of research on courts and litigants in climate governance', WIREs Climate Change, 4 July 2019, available at onlinelibrary.wiley.com/doi/abs/10.1002/wcc.580; J. Peel, 'The Role of Climate Change Litigation in Australia's Response to Global Warming', (2007) 24 Environmental and Planning Law Journal 90; H. M Osofsky, 'The Continuing Importance of Climate Change Litigation', (2010) 1 Climate Law 3; J. Peel, H. M. Osofsky and A. Foerster, 'Shaping the "Next Generation" of Climate Change Litigation in Australia', (2017) 41 Melbourne University Law Review 793; K. Bouwer, 'The Unsexy Future of Climate Change Litigation', (2018) 30 Journal of Environmental Law 483; N. Singh Ghaleigh, "Six Honest Serving Men": Climate Change Litigation as Legal Mobilisation and the Utility of Typologies', (2010) 1 Climate Law 31; J. Peel, L. Godden and R. J. Keenan, 'Climate Change Law in an Era of Multi-Level Governance', (2012) 1 Transnational Environmental Law 24; E. A. Posner, 'Climate Change and International Human Rights Litigation: A Critical Appraisal', (2007) 155 University of Pennsylvania Law Review 1925; R. Abate, 'Kyoto or Not, Here We Come: The Promise and Perils of the Piecemeal Approach to Climate Change Regulation in the United States', (2006) 15 Cornell Journal of Law and Public Policy 369; M. Acevedo, 'The Intersection of Human Rights and Environmental Protection in the European Court of Human Rights', (2000) 8 New York University Environmental Law Journal 437; J. Peel and H. Osofsky, Climate Change Litigation: Regulatory Pathways to Cleaner Energy (2015).

${ }^{7}$ For general analysis of climate change litigation see M. Burger and J. Gundlach, 'The Status of Climate Change Litigation: A Global Review', (2017) UN Environment Program and Sabin Center for Climate Change Law; W. Burns and H. Osofsky (eds.), Adjudicating Climate Change (2009).

${ }^{8}$ Massachusetts v. Environmental Protection Agency, 549 U.S.497 (U.S. Supreme Court 2007).

${ }^{9}$ Gray v. the Minister for Planning and Others, NSWLEC 720 (Land and Environmental Court of New South Wales 2006).

${ }^{10}$ Ashgar Leghari v. Federation of Pakistan, Lahore High Court Green Bench, Orders of 4 September and 14 September 2015, the English version of the order is available at elaw.org/pk_Leghari.

${ }^{11}$ For example, Peel writes that that 'it will be difficult, if not impossible, to identify any injured state' for under the law of state responsibility. See J. Peel, 'New State Responsibility Rules and Compliance with Multilateral Environmental Obligations: Some Case Studies of How the New Rules Might Apply in the International Environmental Context', (2001) 
This strategy has gained momentum in the wake of a few recent judgments by the International Court of Justice (hereafter ICJ) which allegedly opened the way to hold states responsible for environmental damages without the claimant being an injured state under the law of state responsibility. Mention can be made of the case concerning Whaling in the Antarctic, ${ }^{12}$ which was the first to be successfully brought before the ICJ on the basis of a legal claim to protect ocean resources and explicitly meant to address a global environmental problem.

The other strategy witnessed in the current rise of litigation is what is designated here as the rights strategy, a strategy significantly increasing in practice. It consists in the invocation, before national and international courts, of violations of environmental law through the legal categories of international human rights law. ${ }^{13}$ The rights strategy does not need the special jus standi argument as long as the environmental harm can be individualized and amounts to a violation of the litigant's human rights. This strategy is becoming increasingly popular among environmental advocators, as is illustrated by the recent ground-breaking judgment of the Dutch Supreme Court in State of the Netherlands v. Urgenda. ${ }^{14}$ Petitions whose claims are grounded in human rights treaties have been filed in more than ten jurisdictions across Europe, America, and before international human rights bodies. ${ }^{15}$

This article sheds light on the potential and the limits of the abovementioned litigation strategies in international law. The argument builds on the specific evolution in the legal architecture of international obligations under the UNFCCC. The current structure of the UNFCCC makes it substantially impossible to bring a claim against individual states regarding their specific measures regarding climate change. The article, by referring to the history of drafting that produced the specific structure, questions the ability of these litigation strategies to remedy the lack of international consensus and to accommodate the technical intricacy of how to turn normative commitments into actual action against climate change.

The discussion proceeds as follows. After some basic consideration is given to the two abovementioned litigation strategies (Section 2), the article elucidates the legal architecture of the obligations under the UNFCCC to break apart the obligation of a separable nature and the obligation of an inseparable nature amongst the duty bearers (Section 3). The article then elaborates on how the UNFCCC regime is designed to marginalize judicial intervention, which made obligations under the UNFCCC simply not justiciable under the current law of state responsibility (Section 4). It then moves on to the limitations and risks of a resort to international human rights treaties by transposing environmental claims into human rights claims (Section 5). The article ends with a few concluding remarks (Section 6).

10 Review of European Community and International Environmental Law 86. For a similar position see M. Fitzmaurice, 'Responsibility and Climate Change Focus: Climate Change and New Challenges for International Law', (2010) 53 German Yearbook of International Law 89, at 100; see also the reference to Gaja in Section 2.1 of this article.

${ }^{12}$ Whaling in the Antarctic (Australia v. Japan: New Zealand intervening), Merits, Judgment of 31 March 2014, [1994] ICJ Rep. 226. Also, other cases such as Questions Relating to the Obligation to Prosecute or Extradite (Belgium v. Senegal), Judgment of 20 July 2012, [2012] ICJ Rep. 422, made a similar point.

${ }^{13}$ J. Knox, 'Climate Change and Human Rights Law', (2010) 50 Virginia Journal of International Law 163; D. Shelton, 'Whiplash and Backlash - Reflections on a Human Rights Approach to Environmental Protection', (2015) 13 Santa Clara Journal of International Law 11; J. Peel and H. M. Osofsky, 'A Rights Turn in Climate Change Litigation?', (2017) Transnational Environmental Law 1; L. Rajamani, 'The Increasing Currency and Relevance of Rights-Based Perspectives in the International Negotiations on Climate Change', (2010) 22(3) Journal of Environmental Law 391; see Acevedo, supra note 6; see Posner, supra note 6.

${ }^{14}$ Urgenda v. the Government of the Netherlands (Ministry of Infrastructure and the Environment), Judgment of 20 December 2019, 19/00135, Supreme Court of the Netherlands.

${ }^{15}$ As of January 2020, the ongoing cases whose claim is grounded on human rights treaties are identified at least under the following jurisdictions: the Netherlands, Belgium, France, Germany, Ireland, Switzerland, the European Court of Justice, the General Court of EU, the Inter-American Commission on Human Rights, the United Nations, and the UN Committee on the Rights of the Child. 


\section{Litigating climate change through international law: The obligations strategy and the rights strategy}

\subsection{The obligations strategy: Erga omnes status as jus standi before courts}

Traditionally, bringing a case pertaining to the global environment to an international court was considered to be very difficult, if not impossible. For example, Gaja admitted that:

(n)o state would in fact be able to invoke the responsibility of the wrongdoing state. In the case of heavy pollution of the high seas or unlawful harm to the ozone layer, the responsible state would have an obligation of reparation that would not be owed to any other state and would therefore remain theoretical ... for they could easily be breached without consequences. ${ }^{16}$

This specific obstacle to environmental litigation largely originates in the collective nature of the legal interests at stake, and in the limited possibility for the law of state responsibility to accommodate such collective interests, given its primary focus on bilateral and reciprocal rights and duties. It is in this context that the concept of erga omnes obligations has drawn the attention of international lawyers who have found therein a means to expand the standing necessary to bring such cases before international courts. For example, James Crawford, as the International Law Commission (ILC) Special Rapporteur on state responsibility, argued that the conservation of resources amounting to a common heritage of mankind could give rise to obligations erga omnes partes. ${ }^{17}$ Shelton argues that the ICJ recognized the existence of erga omnes environmental obligations in its advisory opinion on the Legality of the Threat or Use of Nuclear Weapons, submitting that the 'common concern' of mankind is necessarily backed up with both institutional arrangements and assurances of enforcement. ${ }^{18}$ In the same vein, Bierman defended the idea that certain fundamental norms for the protection of the environment would confer erga omnes status. ${ }^{19}$ On the contrary, Brunnée, despite recognizing the collective nature of the legal interest in protecting the global environment, acknowledged that it still remains to be seen whether the obligations are bestowed with erga omnes effect due to the lack of practice. ${ }^{20}$

Despite extensive scholarly debates, the nature and possible consequences ${ }^{21}$ remained rather vague and arcane. It was not until the judgment in East Timor ${ }^{22}$ that the implications

\footnotetext{
${ }^{16}$ G. Gaja, 'States having an Interest in Compliance with the Obligation Breached', in J. Crawford, A. Pellet and S. Olleson (eds.) The Law of International Responsibility (2010), 957, at 961.

${ }^{17}$ ILC Third report on State responsibility, by Mr. James Crawford, Special Rapporteur, A/CN.4/507 and Add. 1-4, para. 92.

${ }^{18}$ D. Shelton, 'Common Concern of Humanity', (2009) 5 Iustum Aequum Salutare 33, at 34, 39.

${ }^{19}$ F. Biermann, “Common Concern of Humankind": The Emergence of a New Concept of International Environmental Law', (1996) 34 Archiv des Völkerrechts 426, at 451.

${ }^{20} \mathrm{~J}$. Brunnée, 'International Legal Accountability through the Lens of the Law of State Responsibility', (2005) 36 Netherlands Yearbook of International Law 21, at 32.

${ }^{21}$ For example, E. De Wet, 'The Emergence of International and Regional Value Systems as a Manifestation of the Emerging International Constitutional Order', (2006) 19 LJIL 611; U. Linderfalk, 'International Legal Hierarchy Revisited - The Status of Obligations Erga Omnes', (2011) 80 Nordic Journal of International Law 1; M. Koskenniemi, 'Hierachy in International Law: A Sketch', (1997) 8 EJIL 566; C. Bassiouni, 'International Crimes: Jus Cogens and Obligatio Erga Omnes', (1996) 59 Law and Contemporary Problems 63; O. Lopes Pegna, 'Counter-Claims and Obligations Erga Omnes Before the International Court of Justice’, (1998) 9 EJIL 724; A. de Hoogh, 'The Relationship Between Jus Cogens, Obligations Erga Omnes and International Crime: Peremptory Norms in Perspective', (1991) 42 Austrian Journal of Public and International Law 183; Y. Shigeta, 'Obligations to Protect the Environment in the ICJ's Practice: To What Extent Erga Omnes', (2012) 55 Japanese Yearbook of International Law 176; G. I. Hernández, 'A Reluctant Guardian: The International Court of Justice and the Concept of "International Community", (2013) 83 British Yearbook of International Law 13; E. Cimiotta, 'The Relevance of Erga Omnes Obligations in Prosecuting International Crimes', (2016) ZaöRV 76; C. J. Tams, Enforcing obligations erga omnes in international law (2005).

${ }^{22}$ Case Concerning East Timor (Portugal v. Australia), Judgment of 30 June 1995, [1995] ICJ Rep. 90.
} 
of an 'obligation owed to the international community' ${ }^{23}$ in the light of jus standi were clarified and substantiated by the ICJ. This enhanced jus standi was also codified by the ILC in its Articles on Responsibility of States for Internationally Wrongful Acts (ARSIWA) of 2001. ${ }^{24}$

During the 2010s, the ICJ, making use of the enhanced jus standi codified in ARSIWA, approved the standing of an applicant based on the convention's erga omnes partes nature in its rulings - such as the case concerning the Obligation to Prosecute or Extradite (Belgium v. Senegal) ${ }^{25}$ and Whaling in the Antarctic (Australia v. Japan). ${ }^{26}$ Whaling in the Antarctic is particularly relevant for this article, as the case concerns the protection of a collective interest in resource conservation. In this case, Australia asked the ICJ to declare that the Japanese scientific whaling programme (JARPA II) was not in conformity with Article 8 of the International Convention for the Regulation of Whaling (ICRW), and to order its cessation. ${ }^{27}$ In doing so, Australia relied on the Obligation to Prosecute or Extradite in establishing its standing before the ICJ for the alleged violation of the ICRW, during oral proceedings. ${ }^{28}$ Australia, in establishing the admissibility, ${ }^{29}$ claimed that its legal interest derives from the ICRW, which protects the common interest of the whale population for 'nations du monde ${ }^{30}$ and it implies that the obligation under the ICRW is addressed to all other state parties as '(l)'ensemble des États parties ont un "intérêt juridique". ${ }^{31}$ In the ruling, the ICJ made no reference to the issue of legal interest after it settled the jurisdiction, pursuant to Article 36, paragraph 2 of the ICJ Statute although Australia's claim did not particularly concern its individual legal interest. ${ }^{32}$

In light of the above, the Whaling in the Antarctic litigation comes as a decisive milestone for what is designated here as the obligations strategy. As was explained above, the ICJ long avoided an explicit reliance on erga omnes obligations in the operative parts of its decisions. It is said that this dearth of litigation practice concerning erga omnes obligations has contributed the lack of consensus in the legal discourse around the protection of global environment including climate change. ${ }^{33}$

It is submitted here that the judgment in Whaling in the Antarctic seems to have brought about a change in legal discourses, including in the practice of the ICJ. The notable example is the position defended by ad hoc Judge Dugard in his opinion on the 2018 judgment. In his dissenting opinion, he established an obligation not to engage in wrongful deforestation, and characterized it as 'an obligation erga omnes' ${ }^{34}$ by saying ' $\mathrm{t}$ ] he obligation not to engage in wrongful deforestation that results in the release of carbon into the atmosphere and the loss of gas sequestration

\footnotetext{
${ }^{23}$ Case Concerning the Barcelona Traction, Light and Power Co Ltd (Belgium v. Spain), Second Phase, Judgment of 5 February 1970, [1970] ICJ Rep. 3, para. 33.

${ }^{24}$ The result is reflected in Arts. 42 and 48 ARSIWA.

${ }^{25}$ See Questions relating to the obligation to prosecute or extradite (Belgium v. Senegal), supra note 12.

${ }^{26}$ See Whaling in the Antarctic (Australia v. Japan), supra note 12.

${ }^{27}$ Whaling in the Antarctic (Australia v. Japan), Memorial of Australia, 9 May 2011, at 275-7.

${ }^{28}$ Whaling in the Antarctic (Australia v. Japan), Statement by Boisson de Chazournes on behalf of Australia, in Verbatim Record (CR 2013/18), 29, at 33-4, para. 19.

${ }^{29}$ In response to the question by Judge Bhandari - 'What injury, if any, has Australia suffered as a result of Japan's alleged breaches of the ICRW through JARPA II?' See Whaling in the Antarctic, Verbatim Record (CR 2013/13), at 73.

${ }^{30}$ See Boisson de Chazournes, supra note 28, paras. 17, 20.

${ }^{31}$ Ibid., para. 19.

${ }^{32}$ See Whaling in the Antarctic (Australia v. Japan), supra note 12, paras. 30-41. It must be noted that Japan made no challenge to Australia's standing before the Court except for its objection to the Court's jurisdiction based on Australia's reservation to the Convention. For a similar view on Australia's claim see J. Crawford, 'Chance, Order, Change', (2013) 35 Collected Courses of the Hague Academy of International Law 204.

${ }^{33}$ For example, F. Soltau, 'Common Concern of Humankind', in C. Carlarne, K. R. Gray and R. Tarasofsky (eds.), The Oxford Handbook of International Climate Change Law (2016), 202, at 207; J. Brunnée, 'International environmental law and community interests: procedural aspects', in E. Benvenisti and G. Nolte (eds.), Community Interests Accross International Law (2018), 151.

${ }^{34}$ Certain Activities Carried out by Nicaragua in the Border Area (Costa Rica v. Nicaragua), Question of Compensation, Judgment of 2 February 2018, [2018] ICJ Rep. 15, at 119 (ad hoc Judge Dugard, Dissenting Opinion).
} 
services is certainly an obligation erga omnes'. ${ }^{35}$ With respect to the majority opinion, Judge Dugard provided that it 'failed to make any finding on the valuation of the impairment of carbon sequestration and gas regulation'. ${ }^{36}$ In his reasoning, by virtue of an erga omnes obligation, Nicaragua is obliged to pay compensation not because the forest is a resource belonging to Costa Rica, ${ }^{37}$ but because Costa Rica is 'the State most immediately affected' by the loss of gas sequestration services as the community interest. ${ }^{38}$ While Judge Dugard's opinion does not directly address the issue of admissibility, he argues that the erga omnes status is extended to the obligation regarding loss of gas sequestration. Though such obligation is only presented in general terms, his opinion indicates new opportunities for climate change litigation in line with developing trends in the ICJ cases on erga omnes obligations. ${ }^{39}$

\subsection{The rights strategy: The turn to human rights}

While some lawyers struggle to expand access to the ICJ by establishing the standing based on erga omnes obligations, practice has also shown another tendency to file certain cases concerning climate change on the ground of human rights. ${ }^{40}$ Scholarship also shows that international environmental law claims are more likely to succeed if they can be transposed into human rights claims, notwithstanding controversies like those on the specific right on environmental protection. ${ }^{41}$ Such views build on a number of assumptions such as better developed judicial procedures and the possibility of rights-based-remedy in many jurisdictions. ${ }^{42}$

It must be stressed here that this view did not emerge in a complete vacuum. A number of cases before international human rights courts have held states responsible for action or inaction on environmental degradation as a human rights violation, ${ }^{43}$ even when the creation of the environmental hazards could not directly be attributed to the state. ${ }^{44}$ So far, in these cases, the human rights courts have shown a clear inclination to focus on procedural deficits. If procedural requirements are met, for example, the European Court of Human Rights (ECtHR) will not revise 'the material conclusions of the domestic authorities' unless it is 'in exceptional circumstances'. ${ }^{45}$ The case law is built in such a way as to preserve the discretion of a state to strike the best and fairest

\footnotetext{
${ }^{35}$ Ibid., para. 33 .

${ }^{36} \mathrm{Ibid}$.

${ }^{37}$ The majority opinion of the ICJ accepted that the loss of trees and gas sequestration services by deforestation is a direct consequence of Nicaragua's activities towards Costa Rica. See Certain Activities Carried out by Nicaragua in the Border Area (Costa Rica v. Nicaragua), Question of Compensation, Judgment of 2 February 2018, [2018] ICJ Rep. 15, para. 75.

${ }^{38}$ See Dissenting Opinion by ad hoc Judge Dugard, supra note 34, para. 35.

${ }^{39}$ Outside of environmental cases, the litigation practice of using erga omnes claims is increasing. A notable example is Gambia v. Myanmar based on the Genocide Convention. In its order on provisional measures, the court recognized the existence of a dispute under the Genocide Convention. See Application of the Convention on the Prevention and Punishment of the Crime of Genocide (The Gambia v. Myanmar), Provisional Measures, Order of 23 January 2020 (not yet published).

${ }^{40}$ See International Bar Association Presidential Task Force on Climate Change Justice and Human Rights, Achieving Justice and Human Rights in an Era of Climate Disruption (2014).

${ }^{41}$ See Section 2.2. It must also be noted that no UN treaties include the right to healthy environment as of 2019. The recent Human Rights Committee decision on Portillo Cáceres v. Paraguay (14 August 2019) admitted that environmental harm amounts to a human rights violation under ICCPR, but not a general right to a healthy environment itself. See decision CCPR/C/126/D/2751/2016.

${ }^{42}$ E.g., D. Bodansky, 'Introduction: International Human Rights and Climate Change', (2010) 38 Georgia Journal of International and Comparative Law 511, at 518; V. de la Rosa Jaimes, 'Climate Change and Human Rights Litigation in Europe and the Americas', (2015) 5 Seattle Journal of Environmental Law 165, at 190; see Shelton, supra note 13, at 21-2; see Peel and Osofsky, supra note 13, at 30.

${ }^{43}$ For example, Powell \& Rayner v. United Kingdom, (1990) 12 EHRR 355 (ser. A); Lopez Ostra v. Spain, 20 EHRR. Rep. 277 (1994); Guerra \& Others v. Italy (1998) 26 EHRR; McGinley \& Egan v. United Kingdom (1998) 27 EHRR. Rep. 1; Öneryildiz v. Turkey (2005) 41 EHRR 20; Fadeyeva v. Russian Federation (2007) 45 EHRR 10; the Saramaka People v. Suriname (2007) IACHR Series C no. 172; Tătar v. Romania (2009) ECtHR.

${ }^{44}$ For example, see Lopez Ostra v. Spain, ibid.

${ }^{45}$ See Fadeyeva v. Russia, supra note 43, para. 105.
} 
balance of competing social interests while it developed some modest substantial minimum standards (e.g., an obligation to adopt a legal framework) for a positive obligation to counter the environmental harms that affect enjoyment of human rights. ${ }^{46}$ Following the increasing number of cases that inquire into the nexus between environmental harms and human rights violations, recent developments on the right to a healthy environment under regional human rights bodies are also worthy of mention. ${ }^{47}$

In terms of climate change, linking a threat of climate change to human rights violations is well illustrated by the case filed in 2005 by the representatives of the Inuit with the Inter-American Commission on Human Rights, alleging that the failure of the United States to reduce its greenhouse gases $(\mathrm{GHG})$ emissions amounted to a breach of their obligation to protect human rights. ${ }^{48}$ While the petition was denied, the case was perceived as a sound judicial attempt to indicate the adverse effect of climate change as a potential violation of human rights. ${ }^{49}$ For example, John Knox stated 'the [Inuit] petition raised awareness of the effects that climate change was already having on the Arctic, and of the possibility that those effects could be framed as a threat to human rights'. ${ }^{50}$ David Hunter, evaluating the petition, said that it raised attention to the relationship between global warming and human rights not only in judicial but also in political processes: '[a]lthough not successful legally, the Inuit petition brought substantive international attention to the plight of the Inuit and undoubtedly enhanced their influence and visibility in international climate negotiations'. ${ }^{51}$ The claim of a connection between climate change and human rights was also increasingly defended in the late 2000 s at various political fora, including the UN and regional human rights bodies ${ }^{52}$ and also at the Conference Of the Parties (COP) of the UNFCCC. ${ }^{53}$ A recent advisory opinion by the Inter American Court of Human Rights (IACtHR) ${ }^{54}$ similarly recognizes such an overlap by saying that the impact of climate change affects the right to a healthy environment under the additional protocol and social and cultural rights as an autonomous right on the basis of Article 26 of the American Convention on Human Rights. ${ }^{55}$

Despite increasing interest in linking climate change with human rights, ${ }^{56}$ it must be noted that a 'treaty's recognition of a human right does not mean that any interference with that right by any

\footnotetext{
${ }^{46}$ See, e.g., Öneryildiz v. Turkey, supra note 43.

${ }^{47}$ E.g., the African Charter of Human and People's Rights recognizes the right of all peoples to 'a general satisfactory environment favourable to their development' in Art. 24.

${ }^{48}$ Petition to the Inter-American Commission on Human Rights Seeking Relief from Violations Resulting from Global Warming Caused by Acts and Omissions of the United States (7 December 2005).

${ }^{49}$ For example, M. Limon, 'Human Rights and Climate Change: Constructing a Case for Political Action', (2009) 33 Harvard Environmental Law Review 439; D. B. Hunter, 'Human Rights Implications for Climate Change Negotiations', (2009)11 Oregon Review of International Law 331; J. H. Knox, 'The Paris Agreement as a Human Rights Treaty', in D. Akande et al. (eds.), Human Rights and 21st Century Challenges Poverty, Conflict, and the Environment (2020); H. Osofsky 'The Inuit Petition as a Bridge? Beyond Dialectics of Climate Change and Indigenous Peoples' Rights', (2007) 31 American Indian Law Review 675, at 688, 692-7.

${ }^{50}$ See Knox, ibid., at 3.

${ }^{51}$ See Hunter, supra note 49 , at 337.

${ }^{52}$ See, e.g., documents at infra note 60.

${ }^{53}$ For example, Preamble of Paris Agreement, Cancun Agreement, para. 8.

${ }^{54}$ Advisory Opinion OC-23/18, (Nov. 15, 2017), Inter-American Court of Human Rights, (ser. A) No. 23.

${ }^{55}$ Ibid., paras 47, 63-4.

${ }^{56}$ For example, J. H. Knox, 'Linking Human Rights and Climate Change at the United Nations', (2009) 33 Harvard Environmental Law Review 477; S. Kravchenko, 'Right to Carbon or Right to Life: Human Rights Approaches to Climate Change', (2008) 9 Vermont Journal of Environmental Law 513; M. E. Middaugh, 'Linking Global Warming to Inuit Human Rights', (2006) 8 San Diego International Law Journal 179. See Limon, supra note 49; Hunter, supra note 49; J. D. Taillant, 'Environmental Advocacy and the Inter-American Human Rights System', in R. Picolotti and J. D. Taillaint (eds.), Linking Human Rights and the Environment (2003); S. Humphreys (ed.), Human Rights and Climate Change (2009); S. Mcinerney-Lankford, M. Darrow and L. Rajamani, Human Rights and Climate Change: A Review of the International Legal Dimensions (2011).
} 
actor, anywhere in the world, violates a legal duty, ${ }^{57}$ Given the transboundary character of climate change and the nature of its consequences, transposing an environmental claim into a human rights claim is not as simple as it seems. In fact, neither international treaties nor the jurisprudence by international human rights bodies have provided any guidance about how transboundary harms could be litigated through human rights. It has not even been clear whether the responsibility can feasibly be individualized for a state regarding damages or hazardous effects of climate change. Furthermore, climate change is not an issue that can be typically solved by a single government revising their political priorities among competing domestic interests. In this regard, it is noteworthy that the efforts to litigate climate change through the legal categories of human rights law were historically met with great reservations by states. ${ }^{58}$ For example, Limon described the opposition from both oil-producing and oil-consuming countries during the negotiation for the Resolution $7 / 23$ to request a study on climate change and human rights. ${ }^{59}$ Although the UN organs were mindful of the potential overlap between protection of specific human rights and environmental issues, ${ }^{60}$ they continued to take the position that states are not held responsible for violating human rights merely because of GHG emissions. $^{61}$

Whilst there has been reluctance by international human rights bodies to directly link climate change and human rights treaties, attempts aimed at holding a state individually responsible to act in relation to climate change come to prominence in recent practice before national courts. Among these domestic cases, the Urgenda Foundation v. the Netherlands (2019) ${ }^{62}$ and its use of the European Convention on Human Rights (ECHR) warrants some attention here. In upholding the claim by Urgenda, the Supreme Court of the Netherlands provided that a member state has an obligation to take preventive measures against climate change. It reached this conclusion by characterizing climate change as a threat to the right to life (Article 2) and the right to health and respect for private and family life (Article 8) building upon the case law of the ECtHR to the extent that it is characterized as a national problem. ${ }^{63}$ Then the Court, in holding against the argument by the Dutch government that reducing the adverse effects of climate change greatly depends on the other large emitters' commitments, ${ }^{64}$ found that the Netherlands could be held individually responsible for fulfilling its own obligations. The Court referred to the UNFCCC, wherein each state owes an obligation to reduce GHG emissions regardless of its own emissions being small or large. ${ }^{65}$ As to the content of the obligation, it ordered that the Dutch government must cut its GHG emissions by at least 25 per cent by the end of 2020 (compared to 1990 levels) to effectively

\footnotetext{
${ }^{57}$ See Knox, supra note 13 , at 165.

${ }^{58}$ See, for example, Limon, supra note 49 , at 444-6; see also Knox, supra note 56, at 478.

${ }^{59}$ See Limon, ibid., at 445 .

${ }^{60}$ For example, Office of the UN High Commissioner for Human Rights [OHCHR], Report of the Office of the UN High Commissioner for Human Rights on the Relationship Between Human Rights and Climate Change, UN Doc. A/HRC/10/61 (2009), para. 18. Also, the OHCHR individual report on human rights and climate change (2014) under HRC resolution 19/10.

${ }^{61}$ Ibid., 2007 OHCHR report identifying the three obstacles for directly linking climate change and human rights violation that highlights the different nature of conventional human rights violations and the harm caused by climate change. See para. 70. Knox, with a view to the conclusion of the 2014 individual reports, while attempting to establish the overlap between climate change and full enjoyment of human rights, stated that states are not demanding the cessation of all activities since 'states have discretion to strike a balance between environmental protection and other issues of societal importance, such as economic development and the rights of others'. See J. H. Knox, 'The United Nations Mandate on Human Rights and the Environment', (2017) 42 Revue Juridique de l'Environment 251, at 253.

${ }^{62}$ See Urgenda, supra note 14.

${ }^{63}$ Ibid., paras. 5.1-5.2.4, 5.3.2.

${ }^{64}$ The State of the Netherlands v. Urgenda Foundation, The Hague Court of Appeal, judgment, ECLI:NL: GHDHA:2018:2610 (2018), paras. 30, 60-2.

${ }^{65}$ See Urgenda, supra note 14 , para 5.7.1.
} 
protect human rights. ${ }^{66}$ In conclusion, the Court held the state responsible for the inadequacy of its policy under this minimum standard to be compliant with Articles 2 and $8 .{ }^{67}$

What is remarkable about this new evolution of rights strategy is that the Supreme Court appears to be under much less constraint than international courts in determining the exact level of reduction to be achieved by the state. This requires, on the part of the Court, the balancing of legitimate national interests. However, to the extent it concerns interpretation of international law on climate change, there are issues which cannot go unnoticed in further pursuing a rights strategy. In this regard, the Urgenda case calls for a few observations. The finding of responsibility for inadequate policy measures was based on the Court's composition of 'do its part' ${ }^{\text {'68 }}$ obligation, which was linked to the emissions reduction target of 25-40 per cent by Annex I countries. ${ }^{69}$ This target is based on the global amount of carbon reduction to achieve the purpose of the UNFCCC and the $2^{\circ} \mathrm{C}$ target. Whilst it held that a reduction target of 25-40 per cent is not legally binding, ${ }^{70}$ the Court deployed this standard as reflecting a scientific and political consensus which is meaningful for the Court to be able to interpret the minimum standard for the government to prevent and alleviate the adverse effect on rights under the ECHR. ${ }^{71}$ In this reasoning, the individual obligation of a state is materialized as a part (or a share) of the necessary amount of carbon reduction on the global scale as a result of its interpretation of the international law on climate change. This represents a notable, possibly accidental, effect of the human rights litigation: redesigning the architecture of obligations set by the UNFCCC negotiation by transposing environmental claims into human rights claims to vindicate normative commitments on climate change.

\section{Dual structure of the UNFCCC: Separable obligation and inseparable obligations}

This section expounds on the dual structure of obligations under the UNFCCC following the transformation of the legal architecture of international law on climate change: from a 'top-down' approach represented by the Kyoto Protocol towards a more 'bottom-up' approach embodied in the Paris Agreement. It will be shown that this evolution was informed by an attempt to move away from imposing individually allocated, quantified reduction targets as obligations of international law.

Before the article proceeds, an important preliminary observation is warranted, with a view to contextualizing current international law on climate change and the debates thereon. Mention has been made of top-down and bottom-up approaches as well as the lack of political consensus. Solving environmental problems affects diverse interests in societies. In the specific context of climate change, drastic re-engineering of the entire energy-industrial system and consumption pattern are unavoidable if one wants to achieve a green, net-zero emissions economy, given that a high number of sectors are still deeply dependent on fossil fuels. ${ }^{72}$ Transition to a green economy requires heavy investment to reformulate the way society is managed. The obstacle is that there are many uncertainties about the evaluation of the impact and cost of tackling climate change

\footnotetext{
${ }^{66}$ Ibid., para. 8.3.5.

${ }^{67}$ For the critical view on whether Art. 2 can be applied for 'less ambitious' actions see, e.g., I. Leijten, 'The Dutch Climate Case Judgment: Human Rights Potential and Constitutional Unease', Leiden Law Blog, 22 October 2018, available at leidenlawblog.nl/articles/the-dutch-climate-case-judgment-human-rights-potential.

${ }^{68}$ See Urgenda v. the Government of the Netherlands, supra note 14, paras. 5.7.1-5.7.9.

${ }^{69}$ Ibid., para. 7.2.11.

${ }^{70}$ Ibid., para. 7.1 .

${ }^{71}$ Ibid., para. 6.3.

${ }^{72}$ For example, World Energy Report, 'Energy and Climate Change', 2015, especially at 35-67, available at www.arpa. veneto.it/temi-ambientali/energia/file-e-allegati/WEO2015SpecialReportonEnergyandClimateChange.pdf; 'Chapter 4, Report on the impacts of global warming of $1.5{ }^{\circ} C^{\prime}, I P C C, 2018$, available at ipcc.ch/site/assets/uploads/sites/2/2019/06/SR15 Full_Report_Low_Res.pdf.
} 
depending on national circumstances - including the social discount rate. ${ }^{73}$ It is in this sense that climate change is called a 'super wicked problem', ${ }^{74}$ as we cannot simply identify the individual carbon budget that is legitimately allocated to respective states out of the global carbon budget. ${ }^{75}$

The resulting paralysis from the uncertainty and conflict of interests is what led the move by the UNFCCC from the Kyoto Protocol to the Paris Agreement. The former embodies what is known as a 'top-down approach' characterized with a strong co-ordination, timetables and legal targets based on agreed rules at the international level. The latter is the expression of what is known as a 'bottom-up approach' or 'hybrid approach' meant to preserve the autonomy of states in determination of their contributions. ${ }^{76}$ Hence, international law on climate change on the one hand, aims to enhance the co-operation for collective interest by setting a normative framework at the international level, and on the other hand, the concrete actions required are largely domestic, which concerns the overall re-designing of the way respective societies are managed for 197 state parties under different socio-economic situations. This relationship between international and domestic, top-down and bottom-up, is the key component of the legal architecture of international law on climate change that is embodied in the UNFCCC and related legal documents.

While earlier studies repeatedly associated the obligation and the responsibility concerning climate change with terminologies that indicate a collective nature (i.e., 'common', ${ }^{77}$ 'shared', ${ }^{78}$ or 'integral' ${ }^{79}$ ), both the literature and practice so far have not drawn any distinction between different types of obligations under the UNFCCC and its related legal instruments: separable and inseparable obligations. The following paragraphs explain this dual structure of the obligations and how this structure nuances allocation of responsibility to individual member states.

\subsection{Separable obligation under the climate change regime}

A separable obligation is, for the sake of this article, defined as a commitment, which each party to the UNFCCC is expected to be bound to individually, in spite of the collective nature of damage and the adverse effect of climate change. Article 4 of the UNFCCC imposes an obligation on all state parties to take measures to mediate climate change by addressing anthropogenic GHG emissions. In particular, Article 4.2 provides a more stringent obligation for the state parties listed under Annex I (developed countries) to limit their anthropogenic emissions of GHG, which reflects the common but differentiated responsibility under Article 3. This obligation to reduce emissions is spelled out in concrete terms by the Kyoto Protocol, which specifies the quantified target for emissions limitations under a defined timeframe. Article 3 of the Kyoto Protocol specifies the content of the obligation under Article 4 of UNFCCC, such as the overall emissions

\footnotetext{
${ }^{73}$ The Stern Review is known for supporting policies of reducing emissions by $3 \%$ per year by using a discount rate of $1.4 \%$. Yet other analysis, such as by Nordhaus, criticized Stern's conclusion as too optimistic, as the deployed rate was too low. See N. Stern, The Economics of Climate Change: The Stern Review (2007); W. Nordhaus 'A review of the Stern Review on the economics of climate change', (2007) 45 Journal of Economic Literature 694, at 697-701.

${ }^{74}$ See Levin et al., supra note 4.

${ }^{75}$ There is an attempt by a group of experts to establish the precautionary principle as the ground to hold each state legally responsible for trans-border effects. In so doing, they base the standard of wrongfulness on 'any credible and realistic worstcase scenario' with reference to $2{ }^{\circ} \mathrm{C}$. See Oslo Principles On Global Climate Change Obligations, available at globaljustice.yale. edu/sites/default/files/files/OsloPrinciples.pdf.

${ }^{76}$ For an overview of this transition, e.g., see L. Rajamani, 'Ambition and Differentiation in the 2015 Paris Agreement: Interpretative Possibilities and Underlying Politics', (2016) 65 ICLQ 493, at 502; D. Bodansky, 'The Paris Climate Change Agreement: A New Hope?', (2016) 110 AJIL 289, at 291-2.

${ }^{77 ‘}$ Common but differentiated responsibility', Art. 3.1 UNFCCC.

${ }^{78}$ A. Nollkaemper and D. Jacobs, 'Shared Responsibility in International Law: A Conceptual Framework', (2013) 34 Michigan Journal of International Law 359; D. Kysar, 'What Can Climate Change Do about Tort Law', (2011) 41 Environmental Law 1.

${ }^{79}$ J. Pauwelyn, 'A Typology of Multilateral Treaty Obligations: Are WTO Obligations Bilateral or Collective in Nature?', (2003) 14 EJIL 907.
} 
reduction of six specified gases under Annex A by at least 5 per cent below the 1990 levels for the period 2008 to 2012. Some of the parties to the Protocol participated in the second commitment period between 2013 and 2020 with regards to seven specified gases under the Doha amendment. ${ }^{80}$

The Kyoto Protocol framed the obligation of reducing emissions (mitigation) in the form of an individually allocated carbon budget (or the level of emissions reduction) for Annex I state parties, which are the group of developed states. This centralized and binary approach to the obligation of emissions reduction was subject to change for the post-Kyoto scheme, which is covered by the Paris Agreement. The Paris Agreement adopted 'nationally determined contributions [NDCs]' to reflect a more nuanced classification according to respective national circumstances for all member states. Article 4(2) of the Paris Agreement states that '[e]ach Party shall prepare, communicate and maintain successive nationally determined contributions that it intends to achieve. The Parties shall pursue domestic mitigation measures, with the aim of achieving the objectives of such contributions'. Under NDCs, each state can define its own commitment towards the reduction of emissions in terms of amount and means under respective national circumstances. In so doing, each state is not bound by any qualitative and quantitative targets under the UNFCCC including the $2^{\circ} \mathrm{C}$ under Article 2 of the Paris Agreement.

Under the UNFCCC, mitigation is ranked as the most important approach to address climate change amongst the approaches listed under Article 4. While adaptation, which is also listed under Article 4 of the UNFCCC, has been framed in the form of an obligation of conduct, ${ }^{81}$ mitigation has followed quite a different route. Under the current international consensus reflected in the Paris Agreement, however, the primary obligation is designed to respect the parties' respective domestic policy choices in defining individual routes and scenarios in GHG reduction. The obligation is owed by each state regardless of whether its own emissions caused or will cause adverse effects, and the question of attribution is strategically kept silent.

\subsection{Inseparable obligation under the climate change regime}

The obligation of 'inseparable' nature under the UNFCCC and its related legal instruments poses a fundamental challenge to the current system of the law of state responsibility. For the omission of the obligation, regardless of how many parties did not implement the obligation, all parties are held responsible for this breach, together as one, hence the conduct is not attributable to an individual party. The following expounds the content of inseparable obligation under the UNFCCC and the background on why such conceptualization of obligation was necessary in the light of the negotiation history built on 'top-down' and 'bottom-up' approaches.

Acknowledging climate change as a common concern of humankind in its preamble, Article 2 of the UNFCCC defines the ultimate purpose of the Convention as being 'to achieve, in accordance with the relevant provision of the Convention, stabilization of greenhouse gas concentration in the atmosphere at a level that would prevent dangerous anthropogenic interference with the climate system'. This idea of a long-term emissions ceiling is repeated in Article 2 of the Paris Agreement as the $2^{\circ} \mathrm{C}$ target. Throughout the decades of the UNFCCC negotiations, the nature of this longterm global ceiling has remained controversial. As to the question of whether this long-term ceiling is just an aspirational target or a general obligation under the UNFCCC, the drafting process of the UNFCCC suggests that 'the ultimate purpose' later adopted as Article 2 was treated as a 'general obligation' during the drafting process despite being adopted under the heading of 'purpose'. ${ }^{2}$

\footnotetext{
${ }^{80}$ Doha amendment, available at unfccc.int/files/kyoto_protocol/application/pdf/kp_doha_amendment_english.pdf.

${ }^{81}$ See Art. 4.1(b) UNFCCC.

${ }^{82}$ The negotiating committee categorized stabilization under the heading of 'general obligation' as a collective commitment. See 'Compilation of Possible Elements for a Framework Convention on Climate Change' (20 June 1991) A/AC.237/Misc.2/ Rev.1. Several countries refer to stabilization as the element of general obligation: See 'Compilation of Possible Elements for a Framework Convention on Climate Change Submitted by Delegates' (25 June 1991) A/AC.237/Misc.1/, Addendum 1. Contra,
} 
This ambiguity is also partly due to the uncertainty of the legal effect of climate change being classified as a 'common concern of mankind' ${ }^{83}$ It is well known that resolutions by the General Assembly do not confer legal rights and obligations, yet the possible legal effect attached to climate change being a common concern of mankind has been the object of much scholarly debate. ${ }^{84}$ Arguably, the nature of common concern of mankind provides the legal justification for collective action under a specific treaty. ${ }^{85}$

After the Kyoto Protocol, the political momentum to negotiate metrics for 'the ultimate objective' emerged following increased input from the scientific community, and European political efforts to translate it into a legal temperature target. ${ }^{86}$ In the end, the temperature target was formally endorsed in the Paris Agreement under Article 2, which aims to strengthen the global responses to climate change by ' $[\mathrm{h}]$ olding the increase in the global average temperature to well below $2{ }^{\circ} \mathrm{C}$ above pre-industrial levels' ${ }^{87}$ However, despite being anchored in a legal text, the $2{ }^{\circ} \mathrm{C}$ target and the sum of respective commitments by each party under Article 4 are not legally linked. ${ }^{88}$ In terms of the NDCs, the Paris Agreement did not prescribe any obligation of result and NDCs are self-proclaimed commitments undertaken by each party. Article 4.2 only includes the obligation to 'prepare, communicate and maintain' NDCs, and only 'pursue' the domestic mitigation measures. ${ }^{89}$ In doing so, the parties only 'aim at' reducing the emissions as soon as possible in order to achieve the $2^{\circ} \mathrm{C}$ target under Article $4 .^{90}$

Given this understanding, a number of scholars characterized the Paris Agreement as 'a statement of good intentions, setting forth aspirational goals' without substantive obligations. ${ }^{91}$ On the other hand, it is also debatable that $2^{\circ} \mathrm{C}$ is not a mere aspirational target, as it is deeply integrated into the operation of the varied standards and roadmaps established under the UNFCCC regime. ${ }^{92}$ To this end, some would naturally argue that ' $2{ }^{\circ} \mathrm{C}$ ' must be treated by every member state as a basis for their respective national commitment. However, these polarized claims do not reflect the

D. Bodansky, 'The United Nations Framework Convention on Climate Change: A Commentary', (1993) 18 Yale Journal of International Law 453, at 500.

${ }^{83}$ As to the controversial nature of the qualification of common concern, see T. Cottier et al., 'The Principle of Common Concern and Climate Change', (2014) 52 Archiv des Völkerrechts 293, at 295-6, 301-3.

${ }^{84} \mathrm{P}$. Birnie, A. Boyle and C. Redgwell, International Law and the Environment (2009), at 130; F. Biermann, 'Common Concern of Humankind: The Emergence of a New Concept of International Environmental Law', (1996) 34 Archiv des Völkerrechts 426, at 431. See Cottier, supra note 83.

${ }^{85}$ For example, D. A. French, 'A Reappraisal of Sovereignty in the Light of Global Environmental Concerns', (2001) 21 Legal Studies 376 , at 396 .

${ }^{86}$ For a general overview, for example, see Y. Gao, X. Gao and X. Zhang 'The $2{ }^{\circ} \mathrm{C}$ Global Temperature Target and the Evolution of the Long-Term Goal of Addressing Climate Change-From the United Nations Framework Convention on Climate Change to the Paris Agreement', (2017) 3 Engineering 272.

${ }^{87}$ Art. 2.1(a) Paris Agreement.

${ }^{88}$ The UNFCCC recognizes that commitments by the parties are not sufficient to hold the warming to $2^{\circ} \mathrm{C}$. See 'Synthesis report on the aggregate effect of the intended nationally determined contributions', FCCC/CP/2015/7, available at unfccc.int/ resource/docs/2015/cop21/eng/07.pdf; updated in 2 May 2016, FCCC/CP/2016/2, available at unfccc.int/resource/docs/2016/ cop22/eng/02.pdf. See also 'Global Response to Climate Change Keeps Door Open to 2 Degree C Temperature Limit New UN Report Synthesizes National Climate Plans from 146 Countries', available at unfccc.int/files/press/press_releases_advisories/ application/pdf/20153010_indcs_embargo.pdf.

${ }^{89}$ During the drafting process, the negotiated text put 'pursue' and 'implementation' together, the latter of which was deleted in the latest stage of negotiation: See Draft Paris outcome proposed by the President (9 December 2015) Art. 3.2, available at unfccc.int/resource/docs/2015/cop21/eng/da01.pdf; Draft Paris outcome proposal by the President (10 December 2015) Art. 3.2, available at unfccc.int/resource/docs/2015/cop21/eng/da02.pdf.

${ }^{90}$ Art. 4.1 Paris Agreement.

${ }^{91}$ A.-M. Slaughter, 'The Paris Approach to Global Governance', Project-Syndicate, 28 December 2015, available at www. project-syndicate.org/commentary/paris-agreement-model-for-global-governance-by-anne-marie-slaughter-2015-12?barrier= accesspaylog; in the same vein see R. Falk, Voluntary International Law and the Paris Agreement, 16 January 2015, available at richardfalk.wordpress.com/2016/01/16/voluntary-international-law-and-the-paris-agreement/.

${ }^{92}$ E.g., Oslo Principles, supra note 75. 
history of the negotiations that led to the Paris Agreement, which was meant to uphold the necessary top-down element, while establishing the bottom-up format to allow each state to adapt to respective national circumstances.

If one does not regard $2^{\circ} \mathrm{C}$ as a mere aspirational target, the reading of the UNFCCC and the Paris Agreement together indicates that this objective constitutes a commitment to hold the temperature rise below $2^{\circ} \mathrm{C}$. Contrary to the separable obligation, the long-term target thus comes in the form of an obligation of result. All parties are bound to achieve the collective result of the longterm target of $2^{\circ} \mathrm{C}$, yet the obligation is inseparable amongst the parties. In international law it has been recognized that, in some exceptional situations, an obligation is inseparable as it is shared among multiple states. ${ }^{93}$ For the sake of this article, an inseparable obligation refers to a single obligation shared among states. When an inseparable obligation is breached, the responsibility cannot be individually attributed to one state but to all states bound by the inseparable obligation concerned. ${ }^{94}$ It must be acknowledged that the determination of an inseparable obligation depends on the interpretation of the content of the obligation concerned. As far as the UNFCCC is concerned, it seems that interpreting its content as providing an inseparable obligation is plausible given the history of the negotiations. As will be explained in the next section, the drafting history of the UNFCCC shows that it is not a statement of good intentions but it establishes a new form of legal obligations to withhold the necessity of universality without imposing a top-down allocation of individual ceiling to each party, which was opposed by different parties during the negotiations. ${ }^{95}$ The following section will further expound on how the distinction of separable and inseparable play out to marginalize the role of the judiciary, by illustrating the drafting history of the Paris Agreement. It will illustrate how the UNFCCC marginalized the role of the judiciary in the light of law of state responsibility under international law for each obligation, and then how separable and inseparable obligations are carefully decoupled.

\section{Marginalization and the fall of the obligations strategy}

Suppose that the issue of admissibility ${ }^{96}$ is cleared. As was alluded to above, the erga omnes status of the breached obligation may, arguably, provide the procedural basis for invoking the responsibility of a state in its act or omission with regards to the protection of collective interests. As far as separable obligations are concerned, the characteristic of the injury being 'collective' does not bring any additional legal consequences in attributing the international wrongful act. ${ }^{97}$ While there can be omissions by multiple state parties that lead to the temperature rise, these omissions

\footnotetext{
${ }^{93}$ See Principle 3 of the 2020 Guiding Principles on Shared Responsibility in International Law. See A. Nollkaemper et al., 'Guiding Principles on Shared Responsibility in International Law', (2020) 31 EJIL (forthcoming); N. Nedeski, 'Shared Obligation in International Law' (PhD dissertation, University of Amsterdam).

${ }^{94}$ Nadeski refers to climate change as an example of 'shared positive obligation of result' as it is meant to be implemented by 'all duty bearers', and it is not possible for only one of the duty bearers to breach the obligation. See Nedeski, ibid., at 142 , $169-70$.

${ }^{95}$ The support for detaching the top-down approach from the individual commitments was first found among the submissions of the developed state parties ('umbrella group' parties) to the ADP before COP19 where they adopted the words 'intended nationally determined commitment' (later developed into 'nationally determined commitment' under the Paris Agreement). See, for example, submission by New Zealand (September 2013); submission by the US (17 October 2013); submission by Japan (10 September 2013); submission by Canada (12 April 2013), all available via unfccc.int/process-andmeetings/conferences/past-conferences/doha-climate-change-conference-november-2012/adp-1-2/submissions-from-partiesto-the-adp-2012-2013.

${ }^{96}$ ( $\left.\mathrm{T}\right)$ he erga omnes character of a norm and the rule of consent to jurisdiction are two different things'. See Eastern Timor case, supra note 22, para. 29.

${ }^{97}$ The possibility of individual obligations in addressing collective interest is also articulated by A. Nollkaemper, 'Issues of shared responsibility before the International Court of Justice', in E. Rieter and H. de Waele (eds.), Evolving principles of international law: studies in honour of Karel C. Wellens (2012), at 207.
} 
are attributable to each state, which could give rise to state responsibility concurrently. ${ }^{98}$ Under Article 2 of ARSIWA, an act or omission must (i) constitute a breach under international law, and (ii) be attributable to the states. In this regard, Crawford states that a breach of obligation is identified through the consideration 'given above all to the substance of obligation itself. ${ }^{99}$ This statement reflects Crawford's understanding of the law of state responsibility according to which the nature of the breach under ARSIWA is defined by the content of the obligations under the primary rules of international law. But what is the content of the obligation for individual member states of the UNFCCC prescribed at the international level?

In this regard, it must be emphasized that Article 4.2 of the Paris Agreement leaves the content of the obligation to be worked out at the domestic level under 'nationally determined contributions', which is, by its nature, self-determined by each party to the UNFCCC. Because every state has the discretion to define the content by taking into account priorities amongst different domestic interests, what is prescribed at the international level is only a procedural obligation to determine and register NDCs. In other words, the substance of the obligation is independently determined by each party as a part of domestic policy making. If, then, there is no minimum substantive standard to review the content of efforts at the international law level, how could there be an unlawfulness of international law in the sense of Article 2 of ASRIWA? As was alluded to above, invocation of a claim for state responsibility requires the content of the obligation to be identified at the international level. In this regard, the separable obligation under the Paris Agreement falls short of a standard against which the Court can assess compliance under international law. This discretion of states on the content of the obligation is a stark difference from the Kyoto Protocol, in which the content of the obligation was directly identified through international negotiations in a form of quantified emissions amounts for Annex I countries.

Contrary to separable obligations, the content of what we call an inseparable obligation is explicitly spelled out in the text of Article 2 of the UNFCCC and the Paris Agreement. Yet, as will be shown here, the justiciability of inseparable obligation is questionable, not because of the lack of a fixed substantial standard, but because of a substantive and procedural vacuum under the current law of state responsibility. It is well-known that no mechanism is provided by the ARSIWA when actors from multiple states are blamed for an act or omission that constitutes an 'inseparable' breach. ${ }^{100}$ While such a situation is recognized by the ILC, ${ }^{101}$ international legal literature is 'surprisingly devoid of reference to the circumstances or consequences of multiple state responsibility'. ${ }^{102}$ Unlike the separable obligations, breach of an inseparable obligation is not a mere bundle of bilateral relationships between the harm and omission by a state, nor 'shared responsibility' where a wrongful act can be disaggregated into omissions of different obligations held by multiple states. ${ }^{103}$ When the obligation is inseparable, the breach is attributed to all states.

All these analyses on the marginalizing effect of the judiciary are built upon the key structure of the Paris Agreement, which does not link separable obligation allocated to individual states with the shared commitment to hold the global average temperature rise below $2^{\circ} \mathrm{C}$ in legal terms. The following provides further clarification on this point by referring to the drafting history of the Paris Agreement. As was mentioned in the previous section, some may argue that it is possible for individual states to be held legally responsible for respective carbon budgets, which can be feasibly calculated based on the $2^{\circ} \mathrm{C}$ target for environmental integrity. In this regard, it is indeed

\footnotetext{
${ }^{98}$ Nollkaemper distinguishes several categories of state responsibility in explaining the situation where multiple states have committed an internationally wrongful act that results in a single injury. The separable obligation falls into the category of 'concurrent responsibility'. See Nollkaemper, ibid.

${ }^{99}$ J. Crawford, State Responsibility: General Part (2013), 216.

${ }^{100}$ See Nollkaemper, supra note 97 , at 200.

${ }^{101}$ E.g., Art. 47(1) ARSIWA and Art. 48(1) ARIO '[w] here several States [and/or IOs] are responsible for the same internationally wrongful act, the responsibility of each State[and/or IO] maybe invoked in relation to that act'.

${ }^{102}$ See Nollkaemper and Jacobs, supra note 78, at 363.

${ }^{103}$ As to the definition of shared responsibility, see Nollkaemper and Jacobs, ibid., at 366-8, especially at 368.
} 
the Paris Agreement's intention that its long-term goal ('global stocktake') 'informs' the state parties in terms of NDCs. ${ }^{104}$ Yet, this linking of the $2{ }^{\circ} \mathrm{C}$ target with NDCs contradicts the intention of drafters as it manifests itself in the drafting history of the Paris Agreement.

During the negotiations, the decision whether or not to have the top-down obligation of emissions reduction just as the quantified target written under the Kyoto Protocol was a point of disagreement. As a consequence of intensive negotiations, giving up the idea of establishing the substantial obligation of result - such as an individual carbon budget by disaggregating the $2^{\circ} \mathrm{C}$ target - was the cornerstone in the adoption of the Paris Agreement. In this regard, most of the member states had already acknowledged that NDCs will fall well short of the $2^{\circ} \mathrm{C}$ pathway without 'some form of climate engineering' ${ }^{105}$ This is also the reason why the decision of the COP 21 put the emphasis on finance and technology, including mobilization of 100 billion dollars a year by 2020 in climate finance for developing states, strengthening the Technology Mechanism, and having a Green Climate Fund to support the Technology Mechanism to environmentally and economically bearable climate responses.

The disconnection of NDCs from any 'top-down' element in a legal sense was particularly evident in the text negotiation for what became Article 4 and it is worth recalling some decisive moments of the drafting history. In the light of excluding 'top-down' elements from NDCs, Article 4.3, which some construe as a commitment to progression, ${ }^{106}$ is worth noting here. For Article 4.3, some states fought hard against the possibility that even their past ambitions be the mandatory basis for future NDCs. Article 4.3 now provides '(e)ach Party's successive nationally determined contribution will represent a progression beyond the Party's then current nationally determined contribution and reflect its highest possible ambition .... In the draft of 9 December 2015, the three options [shall] - [should] - [will] were all put down in the text. ${ }^{107}$ For a number of states, [shall] was not acceptable as an introduction of the obligation to progress because it substantially suppresses the freedom to determine NDCs according to national circumstances. As a result of overnight consultation, the proposed text used the recommended [should] to counter the binding element of the progression. ${ }^{108}$ Yet, some member states still considered that this was not enough to ensure that states have the necessary liberty in determining the respective NDCs. In the end, the final text was adopted with the term [will], which is more commonly used in non-binding instruments. ${ }^{109}$ As the negotiation history shows, disconnecting NDCs under Article 4 from any binding 'top-down' element was the gist of the compromise on which the Paris Agreement came to be adopted.

In short, all member states agreed to accept the $2^{\circ} \mathrm{C}$ target as a long-term, collective goal for all, yet adopting it as a legal threshold in defining the respective NDCs was neither intended nor technically feasible. Of course, the drafting process does not frustrate the possibility that the $2^{\circ} \mathrm{C}$ target constitutes a related but independent legal obligation from NDCs. Judging from the history of its formation, the $2^{\circ} \mathrm{C}$ target is not merely aspirational in nature, which constitutes notable development from the understanding in previous instruments such as the Cancun Agreement in 2008. ${ }^{110}$

\footnotetext{
${ }^{104}$ Arts. 4.9 and 14 Paris Agreement.

${ }^{105}$ See Bodansky, supra note 76, at 303; O. Geden 'Policy: Climate advisers must maintain integrity', (2015) 521 Nature 27 , at 28.

${ }^{106}$ E.g., M. Doelle, 'The Paris Agreement: Historic Breakthrough or High Stakes Experiment', (2016) 6 Climate Law 1, at 3; C. Voigt and F. Ferreira, 'Dynamic Differentiation: The Principles of CBDR-RC, Progression and Highest Possible Ambition in the Paris Agreement', (2016) 5 Transnational Environmental Law 285, at 295-6; C. Streck, P. Keenlyside and M. von Unger, 'The Paris Agreement: A New Beginning', (2016) 13 Journal for European Environmental and Planning Law 3, at 5.

${ }^{107}$ Draft text, version 1 of 9 December 2015 at 15:00, available at unfccc.int/process/conferences/past-conferences/parisclimate-change-conference-november-2015/statements-and-resources/negotiating-updates/progress-on-text-draft-paris-outcome.

${ }^{108}$ Draft text version 2 of 10 December 2015 at 21:00 at the URL ibid.

${ }^{109} \mathrm{H}$. Winkler, 'Commentary on Article 4.3', in D. Klein et al. (eds), The Paris Agreement on Climate Change Analysis and Commentary (2017), 148.

${ }^{110}$ E.g., H. Thorgeirsson, 'Objective (Article 2.1)', in Klein et al., ibid., at 123; A. Zahar, 'The Paris Agreement and the Gradual Development of a Law on Climate Finance', (2016) 6 Climate Law 75, at 77; D. Bodansky, J. Brunnée and L. Rajamani, 'Paris Agreement', in International Climate Change Law (2017), 209, at 229-30.
} 
Yet, the drafting process implies that if such a target is not an aspirational one, the maximum that can be claimed on the nature of the $2^{\circ} \mathrm{C}$ target is the obligation that is inseparable among all the duty bearers, i.e., the states parties to the UNFCCC. Hence, a state is not individually held responsible for the level of its contribution being inadequate for $2^{\circ} \mathrm{C}$ trajectories.

Without legally disaggregating the $2^{\circ} \mathrm{C}$ target into individual carbon budgets to be translated into NDCs, the $2^{\circ} \mathrm{C}$ target should be interpreted as a single obligation by all parties to the UNFCCC. Legally speaking, such an inseparable obligation by its very nature does not allow for causal investigation into who contributes to what, or to what extent, thus there can be no individual attribution to each state. Furthermore, even when the claim for a breach of inseparable obligation is formed as several bilateral cases for each respondent, it is very unlikely that the ICJ would be able to exercise their jurisdiction because the legal interest of 'third party' will always form the very subject-matter of the decision, according to the Monetary Gold Principle. ${ }^{111}$ Scholarly efforts have not addressed this legal vacuum. For example, the new 2019 Principles of Shared Responsibility currently being drafted by a group of experts of the law of state responsibility is of limited help with respect to an inseparable obligation. ${ }^{112}$ References are made to sharing responsibility among multiple states for both a single action or distinct actions, ${ }^{113}$ while responsibility in relation to the obligation of inseparable nature is not covered.

While the case law on erga omnes obligations rapidly consolidated itself over the past decade, this section has demonstrated how the UNFCCC, the comprehensive legal body on climate change with 197 member states, came to be built on the centrality of national circumstances in the determination of the obligation of states. This section illustrated that this direction is based on political and technical feasibility of measures to counter climate change, and it inevitably deprives the judiciary of a standard against which the responsibility of the parties can be appraised. ${ }^{114}$

\section{Strengths and pitfalls of the rights strategy}

It has been submitted in this article that the current dual structure of obligations in international law on climate change expresses the transition that took place between the Kyoto Protocol and the Paris Agreement. It has been shown that the fall of the obligation strategy was accompanied by a marginalization of the judiciary, reflecting a conscious decision to preserve room for the political prioritization of states. In this context, it can be anticipated that the rights strategy, particularly at the domestic level, will continue to thrive as a serious way to vindicate normative commitments about climate change. Given its resilience, the rights strategy thus warrants some specific observations. While the deployment of the rights strategy in domestic courts would provide an innovative solution, this section argues that the rights strategy simultaneously runs the risk of simply displacing unsolvable problems from one side to the other.

While the threat of climate change can constitute a violation of human rights law, the claims made in this section are premised on the idea that human rights law and international law applicable to climate change are different in nature, thereby often preventing a claim based on the one being mechanically transposed into a claim based on the other. As is confirmed by the case law, human rights law can impose positive obligations to prevent and alleviate environmental harms. These obligations are associated with the idea of a minimum substantial standard, which sets the

\footnotetext{
${ }^{111}$ Monetary Gold case (Italy v. France, the United Kingdom, and the United States), Preliminary objections, Judgment of 15 June 1954, [1954] ICJ Rep. 19.

${ }^{112}$ See Principles on Shared Responsibility, supra note 93.

${ }^{113}$ Ibid., Principles 2 and 3.

${ }^{114} \mathrm{This}$, of course, does not impede the claim based on obligations of erga omnes nature under customary international law or general principles of law if any.
} 
threshold of lawfulness and unlawfulness. While the concept of standard is also found in international law on climate change, the current consensus under the UNFCCC is not to have it as a threshold of unlawfulness, but to encourage states to revise ambitions towards what is ideal. The 'standard' here is something to be aimed at, but no state is individually bound by it.

When turning claims about climate change into human rights claims, the courts are confronted with standards of a very different nature. ${ }^{115}$ This is well illustrated in the judgment of the Dutch Supreme Court in the Urgenda case, where, in transposing a climate change claim into a human rights claim, the Court held that the Netherlands is individually responsible ('partial responsibility'), building upon its own construction of the individual obligation of the state to 'do its part' through its interpretation of international law on climate change. ${ }^{116}$ In so doing, the Court transformed the nature of the standard under the UNFCCC into a legal threshold of unlawfulness in order to assess the conduct of states under the ECHR by way of interpretation. This is the point of fragmentation created by the Urgenda case. As was alluded to in the previous section, the specific feature of the separable obligation under the UNFCCC was to suspend the question of the allocation of burden in a 'top-down' way. Under the current architecture of obligations under the UNFCCC, no state is held responsible for their contribution being evaluated against a minimum threshold set under international law. In this light, the $2^{\circ} \mathrm{C}$ target under the UNFCCC is, at most, materialized as a collective obligation, which is detached from the quality of lawfulness for the individual conduct. The previous section showed that this architecture reflects the lack of global consensus as to the way to turn our normative commitments into concrete actions.

It must be acknowledged that, to the extent that a right-based claim is explicitly made through the discretion recognized by the case law of human rights courts as well as under international law on climate change, the application of a rights strategy in domestic courts can be an innovative solution to turn a normative commitment into concrete action by the government concerned. ${ }^{117}$ As was alluded to in Section 2, the case law of the ECtHR is built in such a way as to preserve the discretion of states to work out the protection of human rights in the light of other social interests. As was sketched out in Section 3, states have considerable liberty under the UNFCCC to determine what would be the most ambitious action possible to counter climate change while keeping a fair balance between environmental interests and competing interests. This means, in assessing adequacy of such action, that the courts in each state are also free to turn technical and ambitious standards into a legal threshold in order to strengthen the protection of human rights within their own jurisdiction.

In this regard it can be argued that, had the Supreme Court of the Netherlands in the Urgenda case limited itself to this discretion, its judgment would not have proved polemical. Instead, in its December 2019 judgment, the Court identified the individual responsibility of the Netherlands by construing the corresponding individual obligation as reflecting the part of the cause of damage', ${ }^{118}$ drawing upon its interpretation of international law on climate change. Then, it applied a 25-40 per cent target as its threshold of lawful protection under Articles 2 and 8 ECHR. By constructing the legal reasoning in this way, the judgment brought back the pattern of legal thinking whereby a state is held responsible based on a legal threshold, which is internationally determined, rather than simply exercising its own discretion to determine what would work the best for the state within the jurisdiction.

\footnotetext{
${ }^{115}$ Bodansky also touches upon the difference of standards for both branches of law. See Bodansky, supra note 42 .

${ }^{116}$ See Urgenda v. the Government of the Netherlands, supra note 14, para. 5.7.5.

${ }^{117}$ E.g., see Ashgar Leghari v. Pakistan, supra note 10.

${ }^{118}$ See Urgenda v. the Government of the Netherlands, supra note 14, para. 5.7.6. The 'unnecessary' detour to causation discussion is also pointed out by A. Nollkaemper and L. Burgers, A New Classic in Climate Change Litigation: The Dutch Supreme Court Decision in the Urgenda Case, EJIL:Talk!, 6 January 2020, available at www.ejiltalk.org/a-new-classic-inclimate-change-litigation-the-dutch-supreme-court-decision-in-the-urgenda-case/.
} 
At the time of writing this article, there are already multiple cases based on the ECHR including some that follow the same pattern of thinking as Urgenda. ${ }^{119}$ While the example of Urgenda is yet to be generalized and made part of ECtHR case law, ${ }^{120}$ the risk of a generalization of such an approach - which resuscitates a legal threshold that was explicitly left out of the international law on climate change - is not minor. Should the Urgenda approach proliferate, even if only at the domestic level, one would possibly witness the unmaking of 30 years of international law-making on climate change whereby decisions about concrete actions are left to the state without construing its obligation as a 'share' or 'part' of a global carbon budget.

\section{Concluding remarks}

Despite the shared sense of urgency to counter climate change, the global community has not yet developed a coherent understanding of how the future world should act in the face of tremendously diverse national circumstances as well as complex global supply chains. ${ }^{121}$ The body of law on climate change, as found in the UNFCCC, will continue to develop through different channels and at multiple governance levels. ${ }^{122}$ In this regard, climate change litigation can also be seen as 'part of the transnational regulatory dialogue over climate change'. ${ }^{123}$ Yet, not all the dimensions of such a dialogue should be embraced enthusiastically.

This article, drawing on the structure of obligations under the UNFCCC and the lack of global consensus behind, has shed a light on some of the problems associated with specific litigation strategies based on international law. It has, particularly, been argued that the obligations under the UNFCCC regime - which have been possibly identified here as separable and inseparable obligations - are shaped in such a way in order to avoid holding states individually responsible under the current law of state responsibility and thus being apprehended by the judiciary as to the content of respective efforts of emission reduction.

Two final remarks are in order. First, a remark must be formulated on the implications of the argument made here for the litigation strategies discussed in Section 2. Whilst the obligations strategy is frustrated by the dual structure of obligation depicted above, the argument developed here shows that the rights strategy - and the judicial activism that accompanies it - may be a silver bullet in terms of accountability, but it is not always so in terms of protection of the environment. Indeed, it is submitted that pursuit of the rights strategy must be done in such way as to avoid drastic fragmentation of the body of human rights and international law on climate change.

Second, the finding in this article should not be interpreted as frustrating the international legal framework and substantive international obligations to fight against climate change. Moving away from a one-size-fits-all approach, the Paris Agreement and the COP decisions acknowledge the vision of tackling climate change collectively through the various channels of institutionalized international co-operation such as providing financial resources, ${ }^{124}$ transfer of technology, ${ }^{125}$

\footnotetext{
${ }^{119}$ See Peel and Osofsky, supra note 13, at 27-9. See also, supra note 15.

${ }^{120}$ See, e.g., K. Dzehtsiarou, 'European Consensus and the Evolutive Interpretation of the European Convention on Human Rights', (2011) 12 German Law Journal 1730, at 1740; M. Saul, 'The European Court of Human Rights' Margin of Appreciation and the Processes of National Parliaments', (2015) 15 Human Rights Law Review 745, at 751.

${ }^{121} \mathrm{~A}$ symbolic recent example is the gilet jaunes (yellow vests) protest in France, which was triggered by a policy to reduce carbon emissions by $75 \%$ - in part by raising taxes on fuel. Following the increasing protests, the government suspended a planned rise in taxes on petrol and diesel (4 January 2019): Announcement of PM Philippe on this emergency measures to respond to gilets jaunes, available at www.gouvernement.fr/partage/10772-discours-devant-l-assemblee-nationale.

${ }^{122}$ For the idea of transnational environmental law see, e.g., T. Etty et al., 'Transnational Dimensions of Climate Governance', (2012) 1 Transnational Environmental Law 235; J. Peel, L. Godden and R. J. Keenan, 'Climate Change Law in an Era of Multi-Level Governance', (2012) 1 Transnational Environmental Law 245; D. Bodansky, 'Climate Change: Transnational Legal Order or Disorder?’, in T. Halliday and G. Shaffer (eds.), Transnational Legal Orders (2015), 287.

${ }^{123}$ See Peel and Osofsky, supra note 13 , at 27.

${ }^{124}$ Art. 9, particularly 9.1 Paris Agreement; COP decision 1/CP/21, paras. 53-65.

${ }^{125}$ Art. 10, particularly 10.6 Paris Agreement; COP decision 1/CP/21, paras. 66-71.
} 
capacity-building, ${ }^{126}$ and other measures such as education and raising public awareness. ${ }^{127}$ These channels are also necessary components of the long-term and large-scale shifts in economic and social systems in order to realize the sustainable and continuous reduction of global GHG emissions while taking into account respective national circumstances.

\footnotetext{
${ }^{126}$ Art. 11 Paris Agreement. 1/CP/21, paras. 72-84.

${ }^{127}$ Art. 12 Paris Agreement.
}

Cite this article: Meguro M (2020). Litigating climate change through international law: Obligations strategy and rights strategy. Leiden Journal of International Law 33, 933-951. https://doi.org/10.1017/S0922156520000473 